\title{
Two separate subtypes of early non-subplate projection neurons in the developing cerebral cortex of rodents
}

\author{
Ana Espinosa', Cristina Gil-Sanz ${ }^{1,2}$, Yuchio Yanagawa ${ }^{3}$ and Alfonso Fairén ${ }^{1 *}$ \\ 1 Instituto de Neurociencias, Consejo Superior de Investigaciones Cientificas - Universidad Miguel Hernández, San Juan de Alicante, Spain \\ 2 The Scripps Research Institute, La Jolla, CA, USA \\ ${ }^{3}$ Department of Genetic and Behavioral Neuroscience, Gunma University Graduate School of Medicine, Maebashi, Gunma, Japan
}

\section{Edited by:}

Kathleen S. Rockland,

RIKEN Brain Science Institute, Japan

Reviewed by:

Zoltan Molnar, University of Oxford, UK

Kathleen S. Rockland

RIKEN Brain Science Institute, Japan

*Correspondence:

Alfonso Fairén, Instituto de

Neurociencias, Consejo Superior de

Investigaciones Científicas -

Universidad Miguel Hernández,

Campus de San Juan, 03550 San Juan

de Alicante, Spain

e-mail: fairen@umh.es
The preplate of the cerebral cortex contains projection neurons that connect the cortical primordium with the subpallium. These are collectively named pioneer neurons. After preplate partition, most of these pioneer neurons become subplate neurons. Certain preplate neurons, however, never associate with the subplate but rather with the marginal zone. In the present overview, we propose a novel classification of non-subplate pioneer neurons in rodents into two subtypes. In rats, the neurons of the first subtype are calbindin ${ }^{+}(C B)$, calretinin ${ }^{+}(C R)$ and $\mathrm{L}^{+}$and are situated in the upper part of the preplate before its partition. Neurons of the second subtype are TAG- $1^{+}$and are located slightly deeper to the previous population in the preplate. After the preplate partition, the $\mathrm{CB}^{+}, \mathrm{CR}^{+}$and $\mathrm{L}^{+}{ }^{+}$neurons remain in the marginal zone whereas TAG $-1^{+}$neurons become transiently localized in the upper cortical plate. In mice, by contrast, calcium binding proteins did not label pioneer neurons. We define in mice two subtypes of nonsubplate pioneer neurons, either $\mathrm{L} 1^{+}$orTAG $-1^{+} / \mathrm{cn} t n 2^{+}$. We propose these to be the homologues of the two subtypes of non-subplate pioneer neurons of rats. The anatomical distribution of these neuron populations is similar in rats and mice. The two populations of non-subplate pioneer neurons differ in their axonal projections. Axons of $\mathrm{L} 1^{+}$pioneer neurons project to the ganglionic eminences and the anterior preoptic area, but avoid entering the posterior limb of the internal capsule towards the thalamus. Axons of TAG-1+ ${ }^{+}$pioneer neurons project to the lateral parts of the ganglionic eminences at the early stages of cortical histogenesis examined.

Keywords: preplate, marginal zone, pioneer neurons, calcium binding proteins, TAG1/cntn2, L1, rat, mouse

\section{INTRODUCTION}

At the onset of corticogenesis, early-differentiated neurons form a primitive neuropil, the "primordial plexiform layer" (MarínPadilla, 1971), now commonly known as the preplate. Thereafter, the cortical plate develops within the preplate, so that preplate neurons become redistributed between the subplate and the marginal zone. The preplate and its derivatives contain projection neurons, collectively named pioneer neurons, whose axonal arborizations establish the earliest corticofugal projection systems during cortical development. These neurons have traditionally been associated with the subplate. However, certain preplate neurons never associate with the subplate but instead with the marginal zone.

Previous studies of this laboratory have described in rats (Meyer et al., 1998, 1999; Soria et al., 1999; Soria and Fairén, 2000; LópezBendito et al., 2002a,b) and mice (Morante-Oria et al., 2003) both neurochemical and functional features of these projection neurons of the marginal zone. A clear unifying picture has nevertheless not yet emerged, in part because interspecies differences have frustrated any attempt at convincingly classifying these neurons. Therefore, we decided to systematically survey early corticogenesis in rats and mice to further characterize such pioneer neurons. In particular, proteins that are strongly expressed in these neurons facilitated populational analyses of corticofugal axon projections by immunohistochemistry, as an alternative approach to axonal tract-tracing methodologies.
These distinguishing marker proteins included the calcium binding proteins calbindin $(\mathrm{CB})$ and calretinin $(\mathrm{CR})$ in rats (Meyer et al., 1998; Soria and Fairén, 2000). Although CR decorates pioneer cells in the human preplate (Meyer et al., 2000), surprisingly, none of these two calcium binding proteins label early projecting neurons in mice (our own unpublished data). Thus, we searched for alternative immunohistochemical markers to try to identify the homologues in mice of the calcium binding protein-expressing pioneer neurons of rats. We used antibodies to the neural cell adhesion and recognition molecules L1 and TAG-1/cntn2/axonin 1, found previously to label pioneer cells in mice (Morante-Oria et al., 2003). Differences in the expression of these molecules on the cell surfaces helped us to define two major groups of early projection neurons common to rats and mice, one expressing L1 and the second expressing TAG-1/cntn2. On this basis, we analyzed the distribution of these two classes of pioneer neurons in the cortical primordium and the possible existence of differential patterns of corticofugal axonal projections.

The axons of $\mathrm{L}^{+}$neurons project massively to the ganglionic eminences and the anterior preoptic area, but avoid entering the posterior limb of the internal capsule that leads to the dorsal thalamus. The axons of TAG- $1^{+}$neurons remain restricted to the lateral regions of the basal forebrain at the early stages of cortical histogenesis. Additionally, we analyzed the anatomical relationships of these axonal projections with the migrating GABAergic interneurons. By this, we intended to investigate if axonophilic guidance could 
be a possible mechanism for interneuron migration. In preparing the present overview, we have hypothesized that the populations of marginal zone pioneer neurons could be more common across mammals that hitherto accepted. We have essayed to build up a framework for future rigorous studies of the preplate and marginal zone of mammals, including primates and humans. Understanding the bases of the neuronal organization of the early cortical neuropil is of importance for understanding the possible conservation in mammalian evolution of certain neuronal populations found in early non-human fetuses; for example, the so-called pioneer plate (Meyer et al., 2000) and the predecessor cells (Bystron et al., 2006). We thus (1) introduce here the concept of an unexpected diversity among non-subplate projection neurons and (2) highlight the importance of markers that can be used in a rigorous comparison across species.

\section{MATERIALS AND METHODS EXPERIMENTAL ANIMALS}

Pregnant rats and mice were maintained at the animal facilities of the Servicio de Experimentación Animal, Universidad Miguel Hernández. We used Wistar rats, wild type C57Bl6/J mice, heterozygous GAD67-GFP knock-in mice and heterozygous cntn2-EGFP (GENSAT) transgenic mice. GAD67-GFP mice were obtained by targeting the cDNA encoding EGFP to the GAD67 locus by homologous recombination. These animals show fluorescent labeling of GABAergic migratory interneurons (Tamamaki et al., 2003). cntn2-EGFP (GENSAT) mice contain multiple copies of a modified BAC in which EGFP reporter gene was inserted immediately upstream of the coding sequence of the cntn2 gene (Gong et al., 2003). Animals were kept on a 12-h light/dark cycle with constant ambient temperature $\left(21 \pm 1^{\circ} \mathrm{C}\right)$ and humidity $(55 \pm 9 \%)$. Food and water were available ad libitum. Experiments were carried out in accordance with the guidelines of the European Union (2003/65/CE) and Spanish regulations (BOE 252/34367-91, 2005) for the use of laboratory animals and were approved by the Comité Ético de Experimentación y Bienestar Animal, Universidad Miguel Hernández.

\section{IMMUNOHISTOCHEMISTRY}

Midday of the vaginal plug or sperm positivity was considered as embryonic day 0.5 (E0.5). Timed-pregnant dams were anaesthetized by i.p. injection of ketamine (Imalgène 1000, 100 mg/ml, 110 mg/ $\mathrm{kg}$ ) and xylazine (Xilagesic $2 \%, 10 \mathrm{mg} / \mathrm{kg}$ ) and the embryos were extracted by caesarean section. We used brains of E13.5 $(n=14)$ and E15.5 $(n=14)$ Wistar rats; E12.5 $(n=15)$ and E13.5 $(n=15)$ wild type C57B16/J mice; E12.5 $(n=15)$ and E13.5 $(n=15)$ GAD67-GFP knock-in mice and E12.5 $(n=10)$ and E13.5 $(n=10)$ cntn2-EGFP transgenic mice. Embryos were fixed in $4 \%$ paraformaldehyde in PBS. One hundred- $\mu \mathrm{m}$-thick vibratome sections or twelve- $\mu \mathrm{m}$-thick cryostat sections were obtained. Immunohistochemistry protocols were as detailed in Morante-Oria et al. (2003). Primary antibodies included rabbit polyclonal antibodies to CB (Swant, 1:2000), CR (Swant, 1:2000), Tbr-1 (gift from R. Hevner, 1:1000), TAG-1 (gift K. Takeuchi, Nagoya, Japan, 1:1,000) and L1 (gift from F. G. Rathjen, 1:1000); chicken polyclonal antibody to GFP (Aves Labs, 1:4000); mouse monoclonal antibodies 12E3 to PSA-NCAM (gift from T. Seki, 1:1,000), and 4D7 to TAG-1/cntn2 (DSHB, Dodd et al.,
1988, 1:40). Secondary antibodies were conjugated to Alexa Fluor 488, 546 or 647 (Molecular Probes). Zenon rabbit IgG labeling kits (Molecular Probes) were used for immunostaining with multiple rabbit primary antibodies as per manufacturer's instructions.

\section{CONFOCAL MICROSCOPY AND IMAGE MANIPULATION}

Imaging was performed with a Leica TCS SL confocal microscope. Plates were prepared using Adobe Photoshop CS2, and mosaic reconstructions were done using the Photomerge tool of this software package.

\section{RESULTS \\ CALCIUM BINDING PROTEINS CALBINDIN AND CALRETININ CO-LABEL IN RATS A SINGLE POPULATION OF PREPLATE PIONEER NEURONS THAT END UP IN THE MARGINAL ZONE}

Non-subplate pioneer neurons are early generated, long projecting neurons of the cortical primordium that do not associate with the subplate at any stage of development. In previous studies, Meyer et al. (1998) and Soria and Fairén (2000) described such neurons in rat embryos, as forming two separate cell populations characterized by the expression of either one of the calcium binding proteins $\mathrm{CB}$ or $\mathrm{CR}$. We decided to reassess this issue using the enhanced sensitivity and selectivity afforded by confocal microscopy. Here, we present evidence suggesting that projecting neurons associated with the marginal zone co-express the two calcium binding proteins and thus form a unique cell population.

In the E15.5 rat we identified densely packed $\mathrm{CR}^{+}$subpial cells (Figure 1; arrowheads in Figure 1D) that most likely were CajalRetzius cells (Weisenhorn et al., 1994; Meyer et al., 1998). More deeply in the preplate was a compact layer of $\mathrm{CB}^{+}$and $\mathrm{CR}^{+}$cells. Within this band, the most superficial cells in the upper preplate co-expressed both labels, and the deepest ones (Figure 1D) only expressed CB. When the preplate was split at the lateral sectors of the neocortex primordium by the arrival of the first cortical plate neurons, $\mathrm{CB}^{+} / \mathrm{CR}^{+}$neurons separated as in the opening of a zipper (Figures $\mathbf{1 C}, \mathbf{E}$ and $\mathbf{3} \mathbf{B}^{\prime}, \mathbf{C}^{\prime}$ ). The lateralmost edge of the cortex showed that the preplate has already divided into marginal zone and subplate; this lateral extreme of the neocortex primordium contained far more $\mathrm{CB}^{+} / \mathrm{CR}^{+}$cells than the medial regions (Figures 1A-C). $\mathrm{CB}^{+} / \mathrm{CR}^{+}$cells accumulated in the marginal zone, whereas most cells expressing $\mathrm{CB}$ only ("CB${ }^{+}$-only cells") accumulated in the subplate (Figures $\mathbf{1 C , E}$ ) and to a lesser degree in the marginal zone (Figure 1E).

In summary, $\mathrm{CB}^{+} / \mathrm{CR}^{+}$cells in rats were apparent as a unique cell population located first in the upper preplate and thereafter in the marginal zone (Table 1). In the preplate, another population was made up of $\mathrm{CB}^{+}$cells interspersed among the $\mathrm{CB}^{+} / \mathrm{CR}^{+}$cells. Most of these $\mathrm{CB}^{+}$-only cells ended up in the subplate. The radial distribution of the cells could better be represented by a semiquantitative analysis. At levels similar to that shown in Figure 1D, 32\% of a total of 118 cells were $\mathrm{CR}^{+}$cells and were located within a range of 0-20 $\mu \mathrm{m}$ from the pia; $33 \%$ were $\mathrm{CB}^{+} / \mathrm{CR}^{+}$cells and were located at $10-40 \mu \mathrm{m}$ from the pia, and $35 \%$ were $\mathrm{CB}^{+}$-only cells, located at 20-60 $\mu \mathrm{m}$ from the pia. After the partition of the preplate, at a level similar to that of Figure 1E, 31\% of a total of 87 cells were $\mathrm{CR}^{+}$cells located at $0-20 \mu \mathrm{m}$ from the pia, $38 \%$ were $\mathrm{CB}^{+} / \mathrm{CR}^{+}$cells located at $10-50 \mu \mathrm{m}$ from the pia, and $31 \%$ were $\mathrm{CB}^{+}$-only cells located 


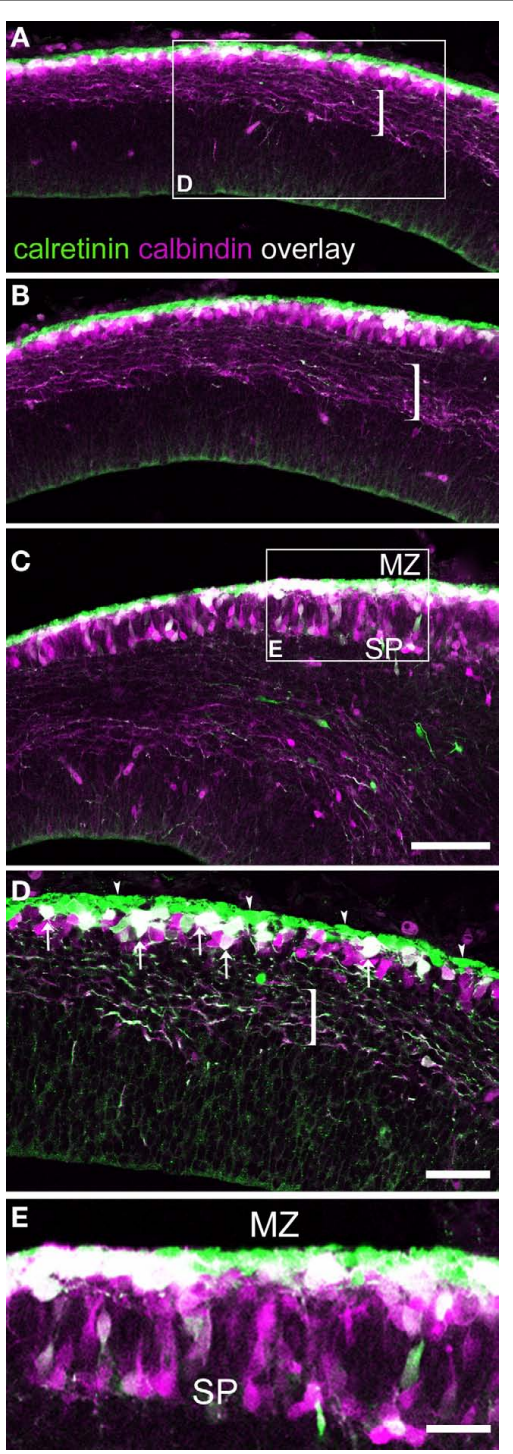

FIGURE 1 | Calcium binding protein expression in the preplate and its derivatives. E15.5 rat. (A-C) are views of single confocal sections of the preplate taken from medial to lateral, displaying a well known latero-medial developmental gradient. (C) shows the partition of the preplate. Brackets indicate pioneer axons emitted by pioneer neurons in the preplate. The majority of these axons co-expressed CB and CR. (D) From the boxed area in

(A): arrowheads indicate a layer of densely packed $\mathrm{CR}^{+}$cells, interpreted as Cajal-Retzius cells. Co-expression of CB and CR appeared in white. Arrows point to double labeled, $\mathrm{CB}^{+} / \mathrm{CR}^{+}$cells. Cells expressing $\mathrm{CB}$ only interspersed among $\mathrm{CB}^{+} / \mathrm{CR}^{+}$cells. (E) From the boxed area in (C): when the preplate became partitioned into marginal zone and subplate, co-expression of $\mathrm{CB}$ and $\mathrm{CR}$ was more common in the marginal zone than in the subplate. $\mathrm{MZ}$, marginal zone; SP, subplate. Calibration bars: (A-C) $100 \mu \mathrm{m}$; (D) $50 \mu \mathrm{m}$; (E) $30 \mu \mathrm{m}$.

at $10-110 \mu \mathrm{m}$ from the pia. Note this range in radial distribution remained unchanged for $\mathrm{CR}^{+}$Cajal-Retzius cells and for $\mathrm{CB}^{+} / \mathrm{CR}^{+}$ cells, while that of $\mathrm{CB}^{+}$-only cells reflected their massive translocation from the preplate to the subplate.

In mice, $\mathrm{CB}$ is a marker for migrating GABA interneurons at the earliest stages of cortical histogenesis (Anderson et al., 1997). We found that in rats as well, CB and CR decorated putative migrating interneurons (Figures 3 and 8). We verified that CB did not label projection, pioneer neurons in the mouse preplate but, contrary to the findings of García-Moreno et al. (2007), we observed CB expression in early migrating GAD67-GFP ${ }^{+}$interneurons that arrived to the preplate before its partition (Figure 2).

\section{THE AXONAL PROJECTION OF CALCIUM BINDING PROTEIN-EXPRESSING PIONEER NEURONS IN RATS AVOID THE POSTERIOR LIMB OF THE INTERNAL CAPSULE}

In our material, Z-stacks of confocal images showed that the corticofugal projection from calcium binding protein-expressing pioneer cells was more extensive than hitherto suspected (Liu and Graybiel, 1992; Meyer et al., 1998; see Figure 6 in Meyer et al., 1999). We show in Figure 3A a compact yet widely distributed $\mathrm{CB}^{+}$axonal bundle that entered the medial ganglionic eminence and the preoptic area. Significantly, these axons avoided the posterior limb of the internal capsule at the ages analyzed. Thus, we can conclude there is no projection to the dorsal thalamus. The bulk of $\mathrm{CB}^{+}$axons originated from cells at medial positions in the cortex, i.e. from cells in the undivided preplate (Figures $\mathbf{3 A}, \mathbf{B}, \mathbf{B}^{\prime}$ ); this was the same for $\mathrm{CR}^{+}$axons (Figures $3 \mathrm{C}, \mathrm{C}^{\prime}$ ). The descending axonal bundle widened progressively as axons were recruited from medial to lateral regions (Figure 3A). Additionally, axons were seen to descend from cells in the lateral areas of neocortex primordium where the $\mathrm{MZ}$ and the subplate had already separated (Figures 3B,C).

\section{ADHESION MOLECULES TAG-1 (cntn2) AND L1 IDENTIFIED TWO DIFFERENT POPULATIONS OF PIONEER NEURONS COMMON TO MICE AND RATS}

The expression of two proteins belonging to the immunoglobulin superfamily of neural cell adhesion and recognition molecules was crucial to our effort to classify pioneer neurons in rodents. TAG-1 (transient axonal glycoprotein-1) belongs to the contactin family; in mice, it is known as contactin $2(\mathrm{cntn} 2)$. TAG-1 is linked to the cell membrane by glycophosphatidyl inositol links. L1 belongs to the L1-CAM family and is a transmembrane protein.

We previously reported in mice the presence of pioneer neurons in the preplate that express TAG-1 and L1 (Morante-Oria et al., 2003). In particular, TAG- $1^{+}$cell bodies formed a conspicuous population in the mouse preplate at E12.5 (Figures $4 \mathrm{~A}, \mathrm{~A}^{\prime}$ ) that was continuous with similar cells in a territory located near the pallial-subpallial boundary, that corresponds to the early mantle of the lateral and ventral pallium, LP/VP (Figure 4A"; see also, Wolfer et al., 1994; Puelles et al., 2000; Denaxa et al., 2001; Morante-Oria et al., 2003). In the E13.5 mouse (Figure 4B), TAG $-1^{+}$axons were more abundant than at previous stages. TAG $-1^{+}$cells distributed medially within the preplate and laterally within the upper part of the cortical plate (Figures 4B, $\mathbf{B}^{\prime}$ and Table 1; see Wolfer et al., 1994; Morante-Oria et al., 2003). TAG $-1^{+}$axons traversed vertically the cortical plate (Figures $4 B, B^{\prime}$ ) to join the main axonal bundle originating in the preplate at more medial regions. In E15.5 rats, the distribution of TAG $-1^{+}$cells and their descending axons was similar (Figures $\mathbf{5 A}, \mathbf{A}^{\prime \prime}$ ). In rats, the descending projections from TAG$1^{+}$neurons partially overlapped with those of $\mathrm{CB}^{+} / \mathrm{CR}^{+}$cells of the preplate and the MZ (Figures 3 and 5A). TAG $-1^{+}$axons were located more laterally at the base of the neocortex, mainly within 
Table 1 |The two basic subtypes of non-subplate pioneer neurons in mice and rats.

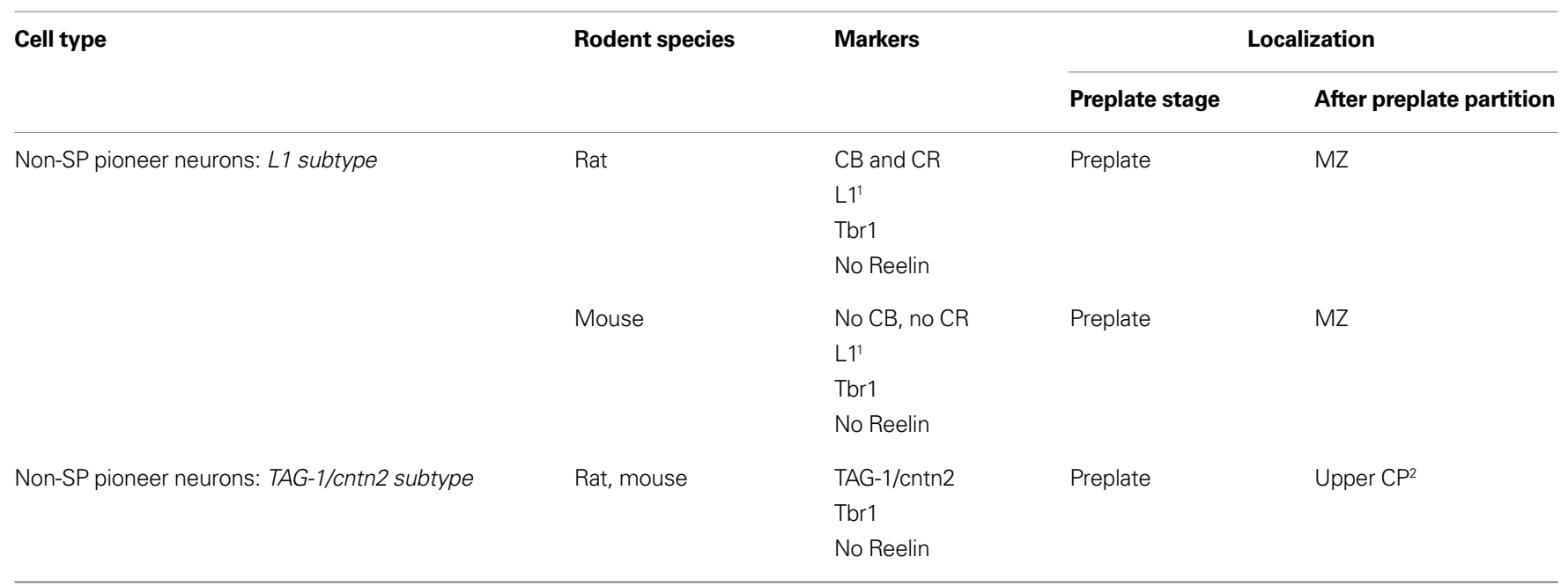

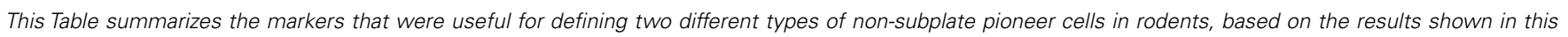
study. CP, cortical plate; MZ, marginal zone; SP, subplate.

' $L 1$ protein accumulated transiently in neuron perikarya, and then it translocated into the projecting axons.

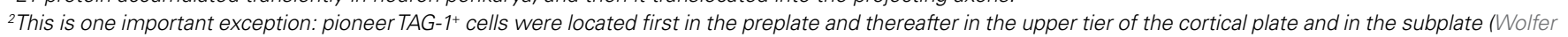
et al., 1994; Morante-Oria et al., 2003; our present results).

the LP/VP mantle. The $\mathrm{CB}^{+} / \mathrm{CR}^{+}$descending axons were more widespread in the MGE and reached more distant places in the MGE than the TAG- $1^{+}$axons (Figure 5A).

Detailed pictures of the relationships between $\mathrm{CB}^{+} / \mathrm{CR}^{+}$and TAG- $1^{+}$cells in the preplate are shown in Figures $\mathbf{5 C}-\mathbf{G}$. As discussed before, the different types of calcium binding proteinexpressing neurons in rats occupied typical radial positions within the cortical primordium. Thus, although CR immunoreactivity is not shown in this Figure, we consider that the $\mathrm{CB}^{+}$cells located close to the pia might belong to the $\mathrm{CB}^{+} / \mathrm{CR}^{+}$population in the $\mathrm{MZ}$, and the deepest ones to the $\mathrm{CB}^{+}$-only cell population in the subplate. The images show that TAG $-1^{+}$and $\mathrm{CB}^{+}$cells did not mutually overlap (Figure 5G, arrows) and, additionally, that TAG- $1^{+}$cells are an important component of the subplate.

$\mathrm{L}^{+}$cell bodies were conspicuous in mice until E12.5. At this stage, $\mathrm{L}^{+}$cell bodies occupied all the extension of the LP/VP mantle

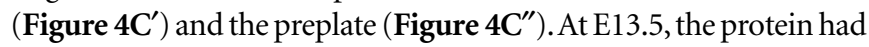
already translocated into axons (Figures $4 \mathrm{C}, \mathrm{D}, \mathrm{D}^{\prime}$ ). $\mathrm{L1}^{+}$axons formed a massive projection from the preplate towards the basal telencephalon both in mice (Figures 4C,D) and in rats (Figure 5B). In rats, the corticofugal $\mathrm{Ll}^{+}$axons overlapped with the $\mathrm{CB}^{+} / \mathrm{CR}^{+}$or $\mathrm{CB}^{+}$-only axons in the ventral forebrain (Figure 5B). Different from the $\mathrm{CB}^{+}$or $\mathrm{CR}^{+}$ axons, $\mathrm{L}^{+}$axons also extended laterally into the LP/VP (Figures 4 and 9). L1 also is expressed by the growing thalamocortical axons (Fukuda et al., 1997), but these axons had not yet reached the ventral forebrain at the ages considered here. Thalamocortical $\mathrm{L1}^{+}$axons in the posterior limb of the internal capsule are shown in Figure 5B.

Given the different tissue distribution of TAG-1 and L1 immunoreactivities, we hypothesized that the expression of these two molecules might define two different subtypes of non-subplate pioneer neurons in the two rodent species analyzed here (Table 1). To analyze this possibility further, we compared the distribution of $\mathrm{L}^{+}$and TAG- $1^{+}$cells in the cortical primordium using cntn2-EGFP mice from GENSAT (Figure 6). We found that $\mathrm{L}^{+}$cells occupied complementary locations to those of cntn2-EGFP ${ }^{+}$cells in the MZ and in the subplate. Initially, $\mathrm{L1}^{+}$cells were located in the preplate, below isolated cntn2-EGFP ${ }^{+}$cells residing subpially (Figures 6A-E, arrowheads). These subpial cntn2-EGFP ${ }^{+}$cells co-expressed Reelin (not shown; see also, Morante-Oria et al., 2003). They can thus be considered as candidate Cajal-Retzius cells, although recent microarray studies have not detected expression of the cntn2 gene in Cajal-Retzius cells (Yamazaki et al., 2004). Leaving aside these cntn2$\mathrm{EGFP}^{+} /$Reelin $^{+}$cells, other cntn2-EGFP ${ }^{+}$cells were deeper in the preplate, at the midway level in the dorsal cortex (Figure 6B). More laterally (Figure 6C), the cortical plate was defined by an accumulation of cntn2-EGFP ${ }^{+}$cells in its upper tier (Figure 6C, asterisks). At this level, $\mathrm{L}^{+}$cells were located in the subplate (Figure 6C, open arrows) together with isolated TAG $-1^{+}$neurons (arrows). Finally, shown in Figure 6D, a palisade of $\mathrm{cntn} 2-\mathrm{EGFP}^{+}$pioneer neurons was seen in the upper cortical plate (asterisks). At this level, some cntn2$\mathrm{EGFP}^{+}$cells were in the subplate (Figure 6D, arrows), as shown also in Figure 5G for rat TAG- $1^{+}$cells. It is our interpretation that the cntn2-EGFP ${ }^{+}$cells in the cortical plate correspond to the images shown in Figure $\mathbf{4 \mathbf { B } ^ { \prime }}$ of TAG- $1^{+}$cells, which are in an identical anatomical localization. In further support of this, we show in Figure $6 \mathrm{E}$ that the cntn2-EGFP ${ }^{+}$cells in the cortical plate were surrounded by TAG-1 immunoreactivity, as would be expected from the extracellular disposition of TAG-1 molecules. Thus, these images must correspond to the cell profiles detected with TAG-1 antibodies in the same location in mice (see Figures 2E,F in Morante-Oria et al., 2003, and our Figures 4B, $\mathbf{B}^{\prime}$ ) and rats (Figure $\mathbf{5} \mathbf{A}^{\prime}$ ).

Finally, we tried to find a plausible correspondence between the pioneer cells expressing neural cell adhesion molecules in rats and mice, and those expressing calcium binding proteins in rats. The data reported so far indicated that TAG-1 would not likely be a candidate marker, so we turned our attention towards L1 as a 


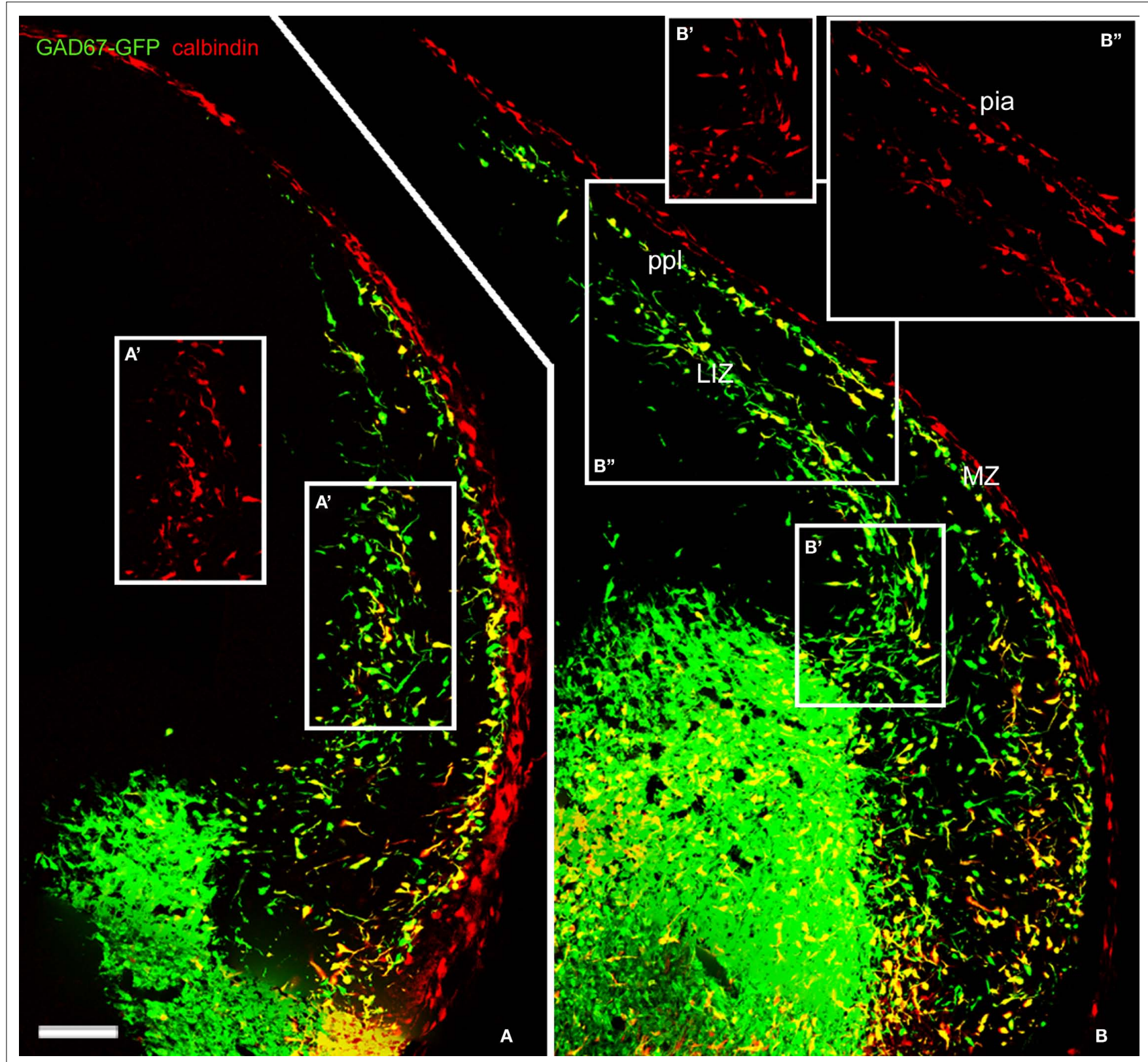

FIGURE 2 | Calbindin labeled migratory GABAergic interneurons in the E13.5 mouse preplate. Migratory interneurons, labeled by GAD67 promoter-driven GFP expression, were seen to leave the ventral forebrain in their way to the pallium, following well-defined migratory pathways at rostral (A) and more caudal levels (B). CB immunoreactivity co-localized with EGFP in only part of the GAD67-GFP interneurons. Boxes represent $\mathrm{CB}^{+}$cells for comparison, at the lower intermediate zone $\left(\mathbf{A}^{\prime}, \mathbf{B}^{\prime}, \mathbf{B}^{\prime \prime}\right)$ and in the preplate $\left(\mathbf{B}^{\prime \prime}\right)$. CB did not label pioneer neurons in mice. Note CB immunostaining at the pia (see Meyer et al., 1998). LIZ, lower intermediate zone; $\mathrm{MZ}$, marginal zone. ppl, primordial plexiform zone or preplate. Photomontages of single confocal sections. Calibration bar: $100 \mu \mathrm{m}$. possible complementary marker of $\mathrm{CB}^{+} / \mathrm{CR}^{+}$cells in rats. In double immunostaining experiments, we observed that the superficial $\mathrm{CB}^{+}$ neurons of the preplate co-expressed L1 (Figure 7). Given their anatomical location in the upper preplate, these $\mathrm{CB}^{+}$cells most likely correspond to the $\mathrm{CB}^{+} / \mathrm{CR}^{+}$pioneer neurons described above. The finding that $\mathrm{L} 1$ labeled in rats a corticofugal axonal projection virtually identical to the projection of $\mathrm{CB}^{+} / \mathrm{CR}^{+}$axons (Figure 5B) further reinforced the conclusion that $\mathrm{L} 1$ was an additional marker of $\mathrm{CB}^{+} / \mathrm{CR}^{+}$cells in rats. Therefore, we postulate $\mathrm{L} 1$ as a marker of a subtype of non-subplate pioneer neurons common to rats and mice. We have summarized these data in Table 1.

\section{PIONEER NEURONS EXPRESS Tbr1}

The T-box transcription factor Tbr1 is expressed early after the differentiation of cortical progenitors, and is functionally important for corticogenesis. Tbrl is expressed by Cajal-Retzius cells, 

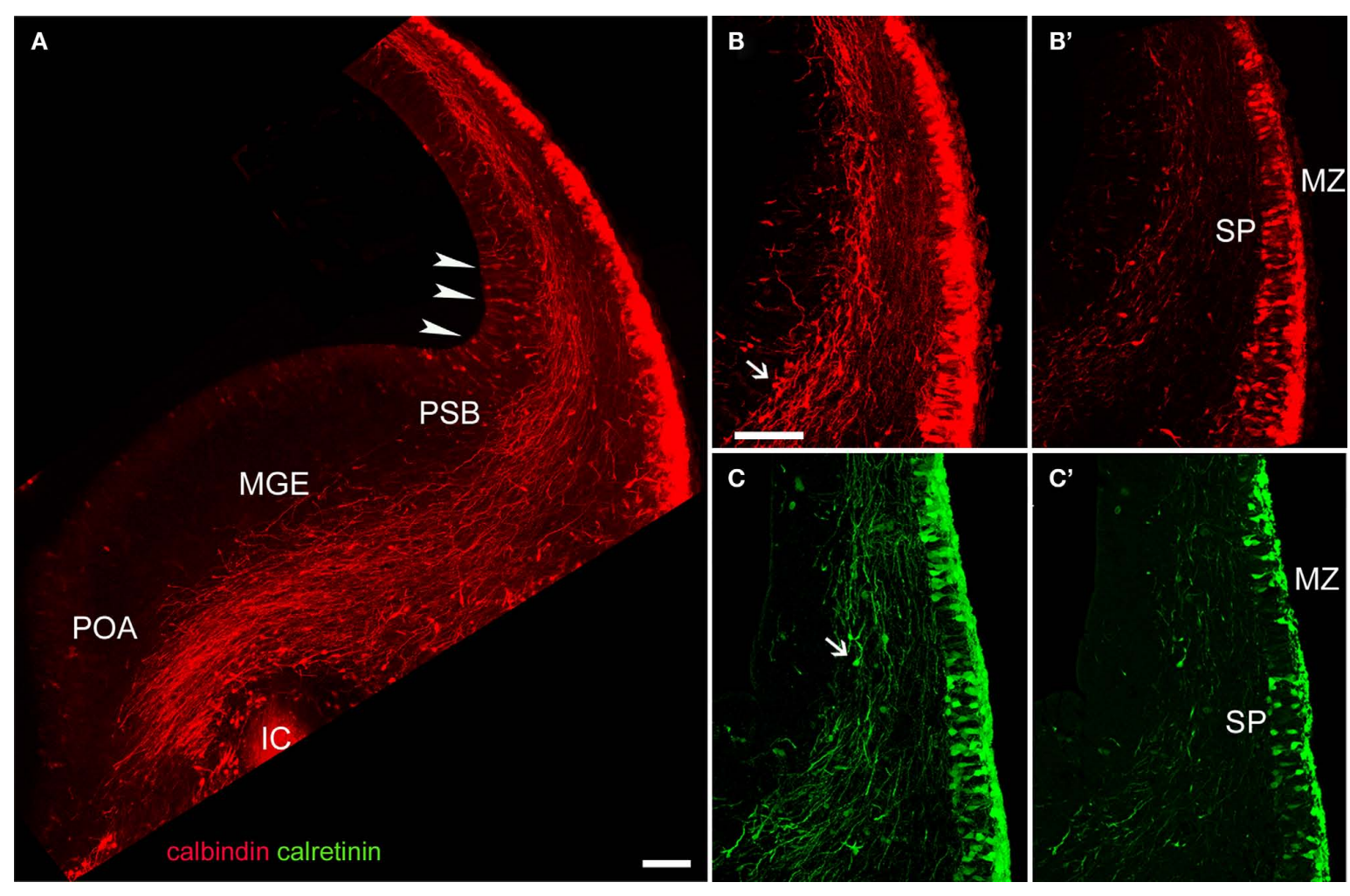

FIGURE 3 | CB and CR immunostaining of a corticofugal projection in E15.5 rats. (A) The dense corticofugal $\mathrm{CB}$ projection from the preplate avoided entering the posterior limb of the internal capsule (IC). Arrowheads indicate $\mathrm{CB}^{+}$cells in the cortical VZ, near the pallial-subpallial boundary (PSB). (B-C') $\mathrm{CR}^{+}$cells were less abundant in subplate than CB cells. Note in (B) and (C) immunostained axons in apparent continuity with the already divided preplate. Arrows in (B) and (C) point to putative migrating interneurons. (A-C) are confocal Z-stacks, $\left(\mathbf{B}^{\prime}\right)$ and $\left(\mathbf{C}^{\prime}\right)$ are single confocal sections. ic, posterior limb of the internal capsule; MGE, medial ganglionic eminence; $\mathrm{MZ}$, marginal zone; POA, anterior preoptic area; PSB, palliosubpallial boundary; SP, subplate. Calibration bars: (A) $200 \mu \mathrm{m}$; (B-C') $100 \mu \mathrm{m}$. subplate cells and glutamatergic neurons, but not by GABAergic cells (Bulfone et al., 1995; Hevner et al., 2001, 2003). Since we characterized the $\mathrm{CB}^{+} / \mathrm{CR}^{+}$cells of the rat preplate and marginal zone as projecting neurons, we wished to confirm that these cells co-expressed the T-box transcription factor Tbr1. This was indeed the case (Figures $\mathbf{8 A - C}$ ), and we additionally observed that Tbr1 was expressed in the mouse preplate by pioneer neurons both of the $\mathrm{L} 1$ and the TAG-1 subtypes (Figures 8D,E).

\section{MIGRATING INTERNEURONS ACQUIRE CLOSE RELATIONSHIPS WITH L1+ AND TAG-1+ CORTICOFUGAL AXONS}

GABAergic interneurons migrate tangentially from the basal telencephalon to the cortical anlage along the intermediate zone and the marginal zone. Given the anatomical overlap of the migration path followed by these interneurons in the intermediate zone and that of the systems of corticofugal axons described here, we explored in detail if corticofugal axons could be a potential substrate for that migration. We used two different markers for migrating interneurons, i.e., GAD67 promoter-driven GFP expression in mice, and PSA-NCAM immunohistochemistry in rats. In E15.5 rats (Figure 9A), PSA-NCAM ${ }^{+}$interneurons maintained contact with $\mathrm{L1}^{+}$axons. In E13.5 mice (Figure 9B), the GAD67-GFP ${ }^{+}$migrating interneurons were also closely related to corticofugal $\mathrm{L}^{+}$axons. Interestingly, in both species, the denser accumulation of migrating interneurons was associated with the fraction of $\mathrm{L}^{+}$axons deployed in the medial part of the intermediate zone, i.e., those axons that distributed in the same territory than $\mathrm{CB}^{+} / \mathrm{CR}^{+}$pioneer neurons in rats.

The lateral tier of $\mathrm{Ll}^{+}$descending axons overlapped with descending TAG- $1^{+}$axons (Figure 9C), and both sets of axons were associated with a sparser population of migrating interneurons. TAG $-1^{+}$axons also occupied a territory crossed by migrating interneurons on their way to the cortical plate (Figure 9C). We are suggesting that TAG- $1^{+}$vertically oriented axons in the cortical plate could serve as potential substrates for interneuron migration from the subplate or the MZ (see also Figure 6E, and Denaxa et al., 2001).

\section{DISCUSSION}

Recent large-scale gene expression analyses (Hoerder-Suabedissen et al., 2009; Osheroff and Hatten, 2009) have revived interest in the roles played by the early-differentiated neurons in the cortical primordium, especially by neurons of the subplate. The use of transgenic mouse lines allows selected neuron subpopulations to be identified and isolated for further analysis, including in-depth genetic analysis or axonal tracing of specific neuron populations with minimal manipulation of the embryos (Gong et al., 2003; Jacobs et al., 2007). These studies are further substantiating the concept that subplate neurons are heterogeneous and encompass different populations of neurons; namely, glutamatergic pioneer 

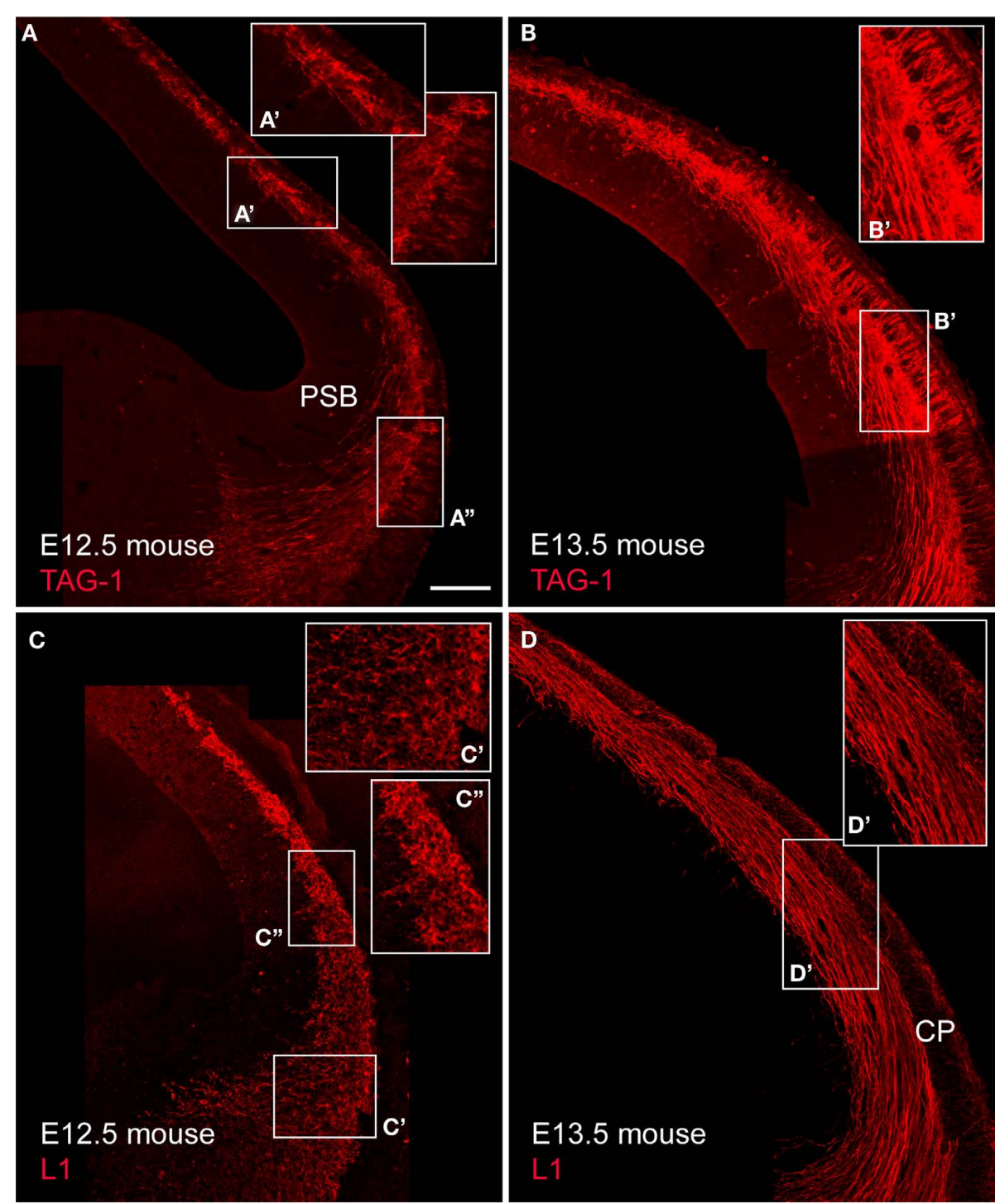

FIGURE 4 |TAG-1+ and $\mathrm{L1}^{+}$cells in the mouse cortical primordium and their axonal projections. (A,B) show TAG-1 expression. Enlarged boxes show $\left(\mathbf{A}^{\prime}\right)$ the dorsal cortex and $\left(\mathbf{A}^{\prime \prime}\right)$ the LPNP territory at E12.5, and ( $\left.\mathbf{B}^{\prime}\right)$ the dorsal cortex at
E13.5, with TAG-1+ cells in the upper cortical plate. (C) and (D) show L1 expression. ( $\left.\mathbf{C}^{\prime}\right)$ shows the LPNP mantle and $\left(\mathbf{C}^{\prime \prime}\right)$ the dorsal cortex at E12.5, and (D') the dorsal cortex at E13.5. Single confocal sections. Calibration bar: $100 \mu \mathrm{m}$. neurons, other types of glutamatergic neurons and GABAergic interneurons in their migration into the cortical plate (reviewed in Hevner and Zecevic, 2006). As we have shown, additional cohorts of early-differentiated neuron populations co-exist with subplate neurons in the developing cortex. In particular, we have focused our attention on one such cohort that we named non-subplate pioneer neurons. This name summarizes the fact that these neurons never associate with the cortical subplate along the course of their development.

Our definition of non-subplate pioneer neurons implies their transient settlement in the preplate and, as development progresses, their incorporation into the MZ. In the case of the TAG $-1^{+}$neurons, incorporation is into the upper tier of the cortical plate. Regrettably, nonsubplate projection neurons have received far less attention than subplate neurons in recent literature. The intent of our present work has been to call attention to the important contribution of these non-subplate neurons to a network of neuron connections in the developing cortex, and to the need for further functional analyses. Additionally, we tried to set the bases for a rigorous comparative approach to evaluate early-differentiated cortical neurons across mammals.

We have identified two subtypes of non-subplate pioneer neurons in rats: the cells of the first subtype co-express $\mathrm{CB}$, CR and L1 and are situated in the upper part of the preplate before its partition. Cells of the second subtype are characterized by the expression of TAG-1 and are located slightly deeper than the previous population in the preplate. After the preplate partition, the neurons co-expressing $\mathrm{CB}, \mathrm{CR}$ and $\mathrm{L} 1$ remain in the marginal zone whereas those expressing TAG-1 become localized in the upper cortical plate. In mice, we identified two subtypes 


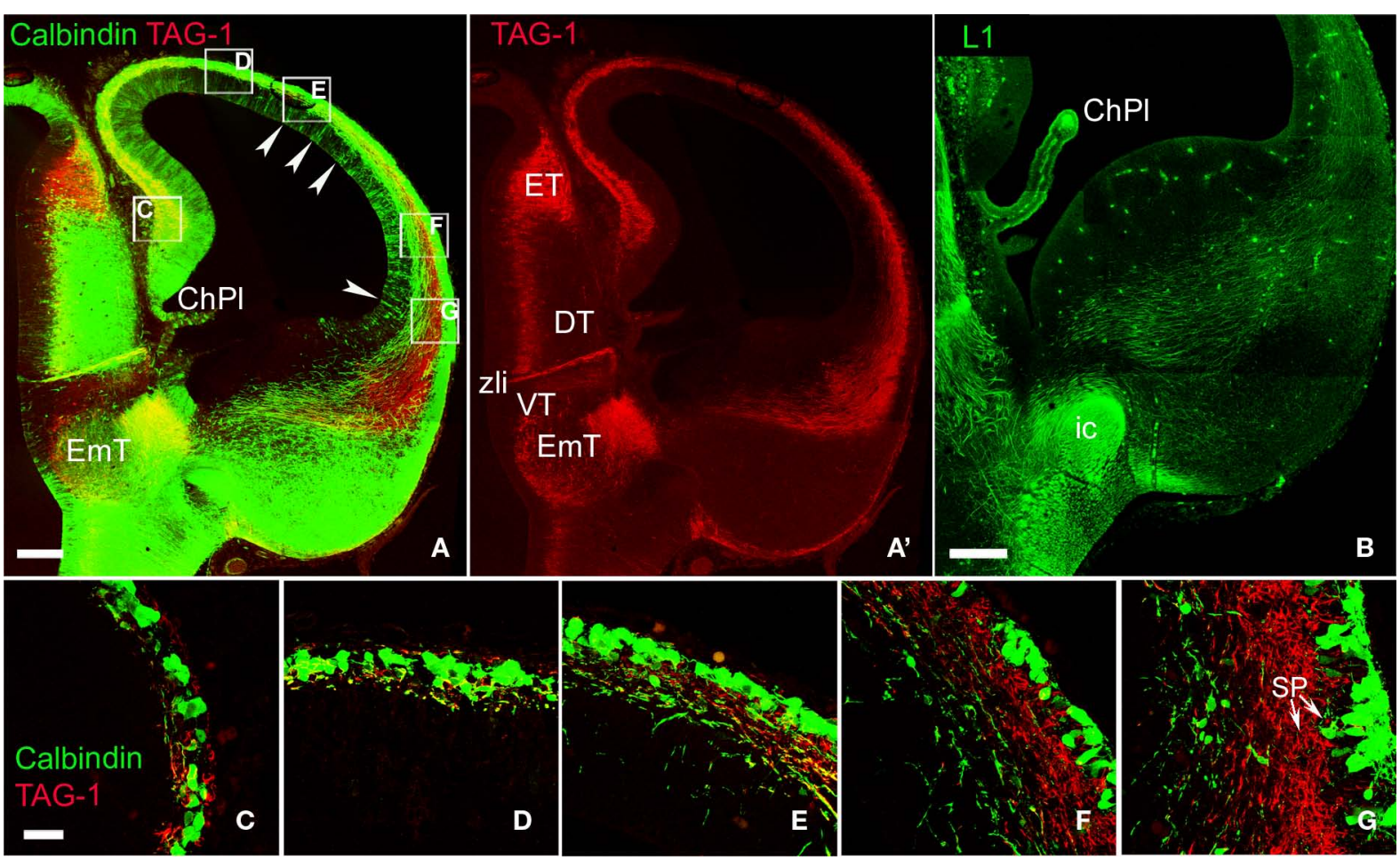

FIGURE 5 | Comparison of the axonal projections of $\mathrm{CB}^{+}$andTAG-1+ neurons in rats. (A) Shows a fluorescence overlay of both markers and ( $\left.\mathbf{A}^{\prime}\right)$ shows TAG-1 immunoreactivity separately. Note that the territory of distribution of TAG-1+ axons overlaps only partially with that of $\mathrm{CB}^{+}$axons. Arrowheads in $(\mathbf{A})$ point to $\mathrm{CB}^{+}$cells in the ventricular zone. (B) Distribution of $\mathrm{L} 1^{+}$corticofugal axons avoiding the posterior limb of the internal capsule. (C-G) show high magnification fluorescence overlays of the boxed areas in (A). Note the lateral-to-medial development gradient, where TAG-1+ or $\mathrm{CB}^{+}$cells accumulated in the ventrolateral extreme of the subplate. CB andTAG-1 localized in independent tissue elements. Note in (G) that subplate contained both TAG-1+ cells and the deepest $\mathrm{CB}^{+}$cells (arrows). ChPI, choroid plexus; DT, dorsal thalamus; EmT, Eminentia thalami; ET, epithalamus; ic, posterior limb of the internal capsule; SP, subplate. VT, ventral thalamus; VZ, ventricular zone; zli, zona limitans intrathalamica. Rat, E15.5. Confocal Z-stacks. Calibration bars: (A,A') $100 \mu \mathrm{m}$; (B) $200 \mu \mathrm{m}$; (C-G) $30 \mu \mathrm{m}$.
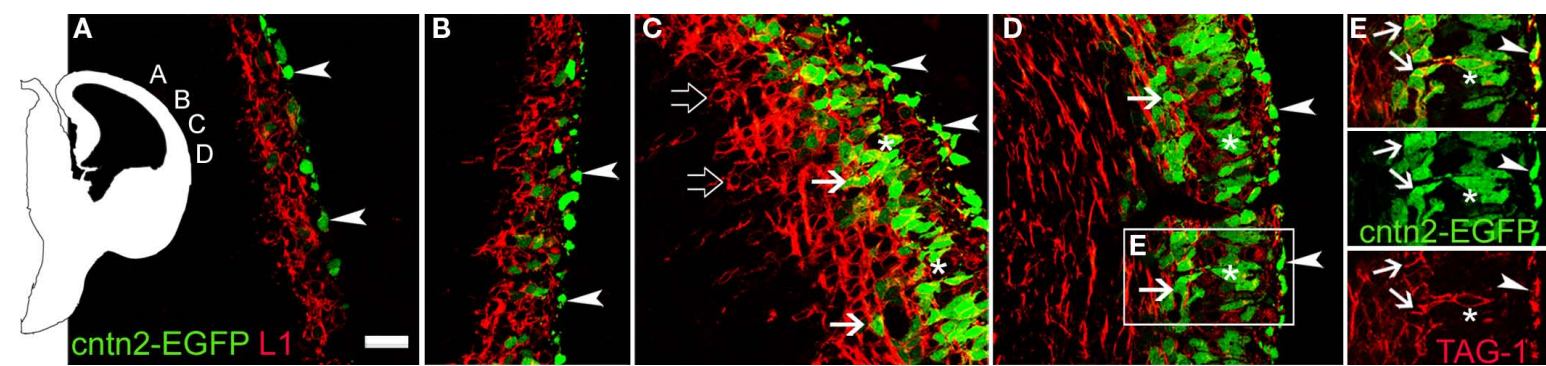

FIGURE 6 | Complementary distributions of L1+ neurons and cntn2-EGFP+ neurons in the cortical primordium of E12.5 mice. The scheme on the left indicates the places were photomicrographs were taken. (A) cntn2-EGFP ${ }^{+}$subpial cells [arrowheads, also in (B-E)], interpreted as Cajal-Retzius cells, and deeper L1+ cells in the preplate. (B) The preplate was filled with $\mathrm{L} 1^{+}$cells, and a few cntn2$\mathrm{EGFP}^{+}$cells interspersed among them. (C) $\mathrm{L} 1^{+}$cells concentrated in the $\mathrm{MZ}$ below cntn2-EGFP+ ${ }^{+}$Cajal-Retzius cells, and in the subplate (open arrows). cntn2-EGFP+ cells located in the incipient cortical plate (asterisks), and a few were in the subplate (arrows). (D) At this lateral level, cntn2-EGFP+ cells were in the subplate (arrows), and inside the upper cortical plate (asterisks). (E) From the boxed area in (D): cntn2-GFP+ cells in the upper cortical plate (asterisks) were surrounded by TAG-1 immunoreactivity. The latero-medial gradient of maturation suggests that cntn2-EGFP ${ }^{+} / \mathrm{TAG}-1^{+}$cells in the subplate (arrows) appeared later than in the upper cortical plate. E12.5 mouse. Single confocal sections. Calibration bar: $30 \mu \mathrm{m}$. of non-subplate pioneer neurons that express either L1 or cntn2 (TAG-1). We propose that these two subtypes of mouse cells are homologues of the two subtypes of non-subplate pioneer neurons of the rat, shown to respectively co-express $\mathrm{CB}, \mathrm{CR}$ and L1, or TAG-1. The anatomical distribution of these neuron populations is identical in rat and mouse. Additionally, non-subplate pioneer neurons in both rats and mice are not GABAergic and in both species express the T-box transcription factor Tbr1, so that they are putatively glutamatergic (Hevner et al., 2001). Table 1 and the scheme in Figure 10 summarize the major aspects of the anatomical distribution of these cells and the markers that are shared by these cells in rats and mice. 


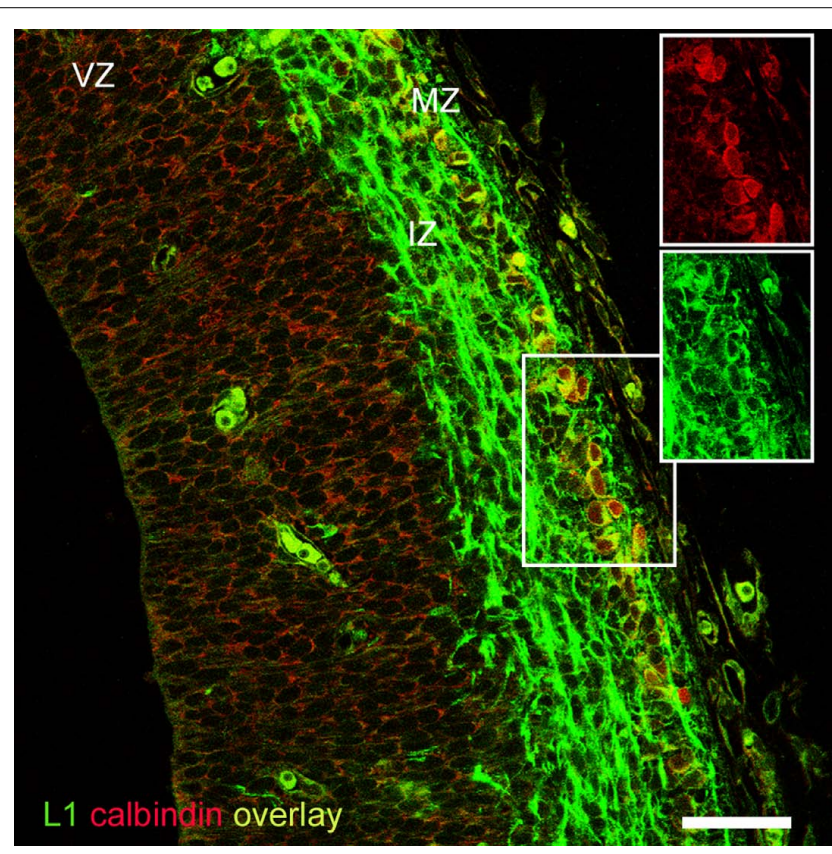

FIGURE 7 | $\mathrm{CB}^{+}$pioneer cells in the rat preplate co-expressed L1. Note the axonal projection of $\mathrm{L}^{+}$cells along the intermediate zone. Although adequate to revealing $\mathrm{CB}^{+}$cell bodies, Zenon immunostaining was not sensitive enough to detect $\mathrm{CB}^{+}$axons. Boxes show the separation of the fluorescence channels. Rat E15.5. Single confocal section. IZ, intermediate zone; $M Z$, marginal zone; VZ, ventricular zone. Calibration bar: $50 \mu \mathrm{m}$.
The different populations of non-subplate pioneer neurons differ in their axonal projections (Figure 11). Non-subplate pioneer neurons of the L1 subtype project to the ganglionic eminences and the anterior preoptic area, but avoid following the internal capsule into the dorsal thalamus. The projections of the neurons of the TAG-1 subtype end up at the lateral parts of the ganglionic eminences. A corticothalamic TAG- $1^{+}$projection becomes apparent much later, in postnatal mice (Wolfer et al., 1994).

Apparent differences in anatomy and tempo of deployment of early axonal projections of subplate vs. non-subplate neurons may result from technical factors; that is, the different advantages and pitfalls of the axonal tract-tracing methods utilized in different studies (e.g., McConnell et al., 1989; de Carlos and O'Leary, 1992; Clascá et al., 1995; Molnár et al., 1998; Molnár and Cordery, 1999; Jacobs et al., 2007). Here, we decided to trace axonal projections by taking advantage of the chemical properties of the early neurons, as detected by immunohistochemistry. In fortunate cases, this approach produced selective staining of different neuronal populations together with high resolution anatomical detail of their projecting axons.

A major discrepancy among the various studies of the early corticofugal connections concerns whether or not subplate axons are considered as reaching the dorsal thalamus (McConnell et al., 1989; de Carlos and O'Leary, 1992), or, according to more recent studies, these subplate axons (and axons deriving from the marginal zone) are considered as entering only the part of the internal capsule that traverses the ganglionic eminences (Meyer et al., 1998; Molnár et al., 1998; Molnár and Cordery, 1999). However, subplate axons seem not
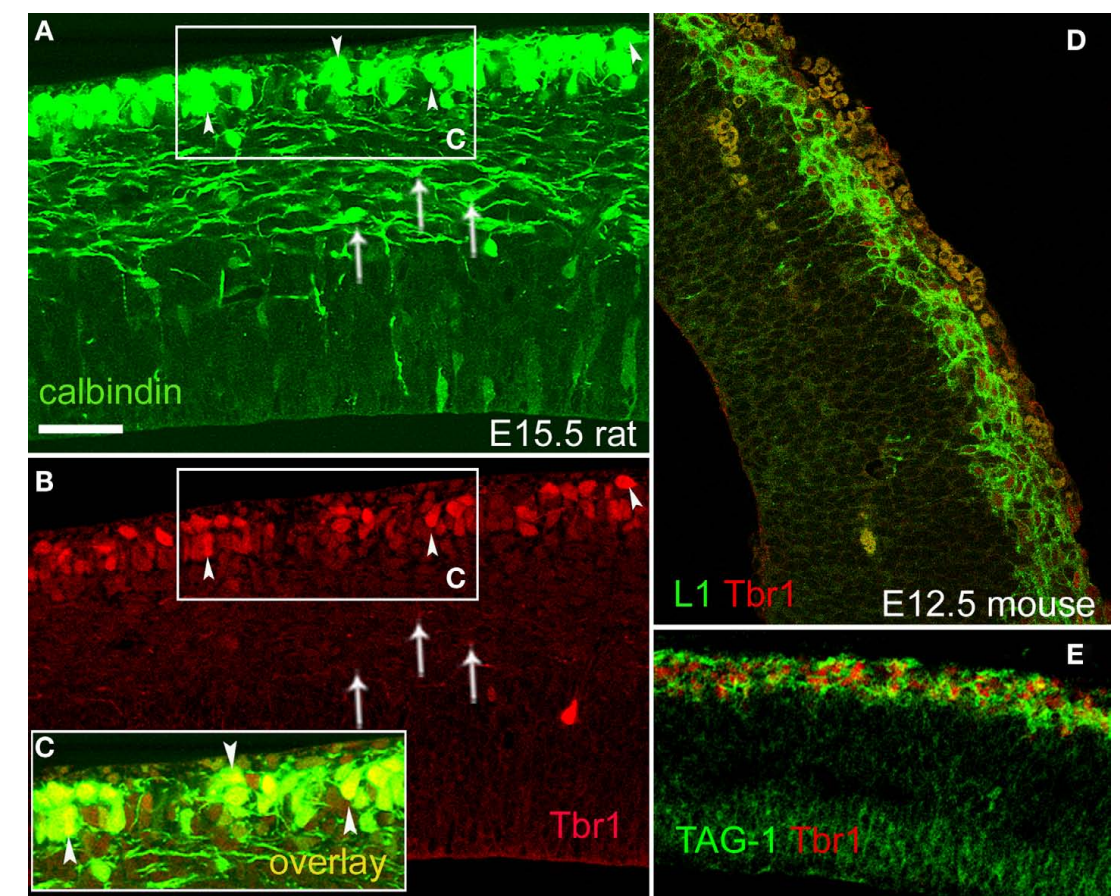

FIGURE 8 | Pioneer neurons in the preplate co-expressed Tbr1 in rats and mice. (A-C) $\mathrm{CB}^{+}$preplate cells co-expressedTbr1; E15.5 rat. Arrowheads signal co-labeled cells. Overlay is shown in the boxed area (C). $\mathrm{CB}^{+}$cells in the intermediate zone (arrows), possibly migrating interneurons, were Tbr1-negative. $\mathrm{CB}^{+}$cells in the ventricular zone (in $\mathbf{A}$ ) were also Tbr1-negative. (D) $\mathrm{L}^{+} / \mathrm{Tbr} 1^{+}$cells in the E12.5 mouse preplate. (E) TAG $-1^{+} / \mathrm{Tbr} 1^{+}$ cells in the E12.5 mouse preplate. Single confocal sections. Calibration bar, $50 \mu \mathrm{m}$, in (A). 

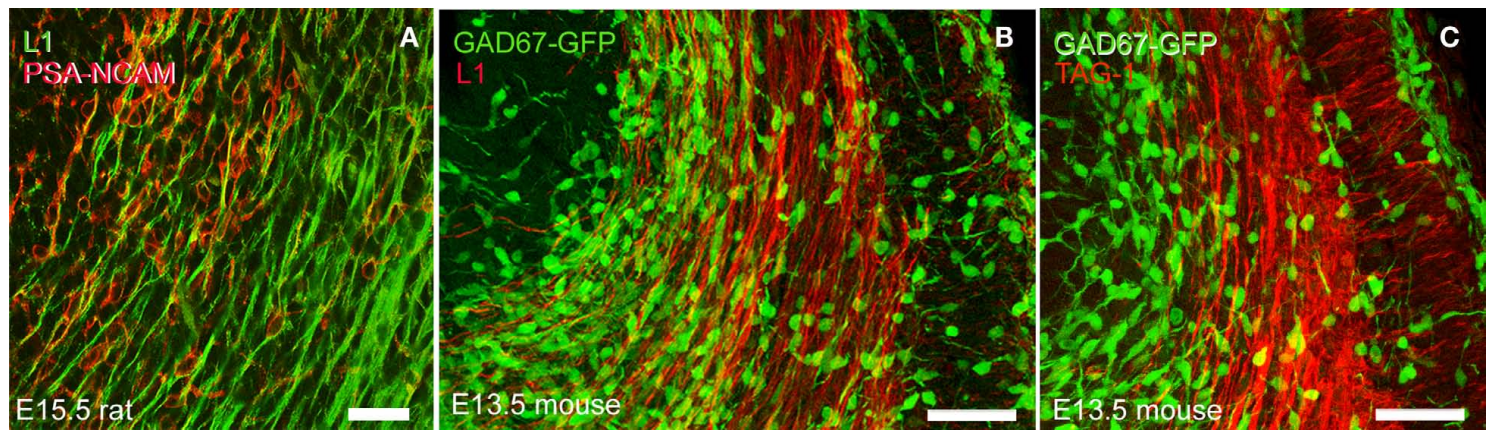

FIGURE 9 |The microanatomical proximity of migratory interneurons with $\mathrm{L1}^{+}$and TAG-1+ axons. (A) PSA-NCAM+ migratory interneurons associated with $\mathrm{L}^{+}$axons in an E15.5 rat. (B) GAD67-GFP+ migratory interneurons in E13.5 mice in contact with $L 1^{+}$axons. In both species, the bulk of migratory GABAergic interneurons exiting from the ganglionic eminences occupied a medial territory, where they overlapped with $\mathrm{L} 1^{+}$axons. A less dense population of migrating interneurons located more laterally also overlapped with $\mathrm{L} 1^{+}$axons. (C) GAD67-GFP+ migratory interneurons in E13.5 mice in contact with TAG-1+ axons. The sparse population of interneurons located at the lateral tier of the migratory path could associate with TAG-1+ ${ }^{+}$axons, which accumulated below the subplate. Vertically oriented TAG-1+ axons and cell bodies in the cortical plate could interact with interneurons entering this compartment. Calibration bar: (A) $30 \mu \mathrm{m}$. (B,C) $50 \mu \mathrm{m}$.

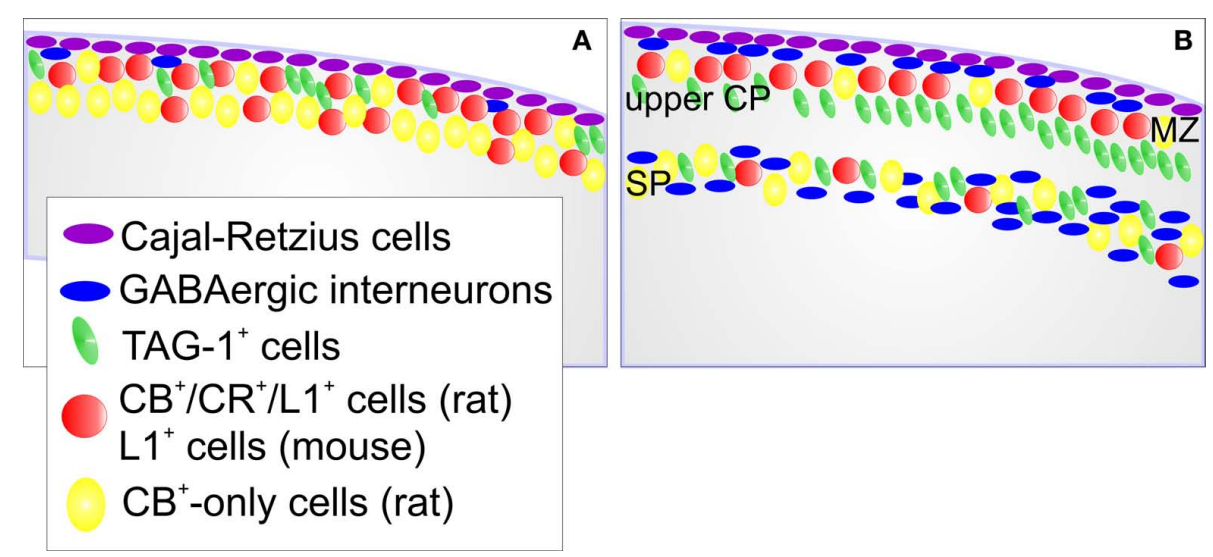

FIGURE 10 |Scheme of the cellular composition of the preplate and its derivatives in rodents. (A) Preplate stage. Cajal-Retzius cells, and sparse GABAergic interneurons are in a subpial sublayer of the preplate. Cells that express $C B, C R$ and $L 1$ in rats, or the homologue $L 1^{+}$cells in mice, locate in the upper preplate. TAG-1+ cells are also in the upper preplate in both species. In rats, cells that express $\mathrm{CB}$ but not $\mathrm{CR}$ ( $\mathrm{CB}^{+}$-only cells) tend to localize deeper in the preplate. (B) This scheme reflects the situation immediately after preplate partition. Cajal-Retzius cells remain in their subpial position. GABAergic interneurons are now apparent in the marginal zone and the subplate. Most of the $\mathrm{CB}^{+} / \mathrm{CR}^{+} / \mathrm{L} 1^{+}$cells (rats) or $\mathrm{L} 1^{+}$cells (mice) end up in the marginal zone. TAG-1+ cells end up in the upper cortical plate and in the subplate. In the subplate, the packing density of TAG-1+ cells increases from medial to lateral (not shown). Most of the $\mathrm{CB}^{+}$-only cells become subplate neurons. $\mathrm{MZ}$, marginal zone; upper $\mathrm{CP}$, upper tier of the cortical plate; SP, subplate. to project to the dorsal thalamus at the initial steps of corticogenesis (Clascá et al., 1995; Molnár et al., 1998; Molnár and Cordery, 1999; Jacobs et al., 2007). If this is so, the subcortical distributions of subplate axons are similar to that of the non-subplate axons described here.

One caveat: both adhesion molecules TAG-1/cntn2 and L1 are simultaneously expressed by different neurons of the marginal zone and the subplate. This makes it hard to distinguish which descending corticofugal projections originate from neurons located in each one of these two transitory cortical compartments, or from neurons residing in both places. Unfortunately, this seems to somewhat limit the usefulness of most neurochemical markers of the marginal zone and the subplate described so far. For example, the recent study by Osheroff and Hatten (2009) described diverse populations of neurons in the preplate, marginal zone and subplate expressing phosphodiesterase 1c (Pde1c). In particular, preplate Reelin-negative
Pde1c-EGFP neurons below Cajal-Retzius cells may share some characteristics with the L1 and TAG-1 neuron subtypes presented here in the same location, but these Pdelc-EGFP cells may distribute in the marginal zone and the subplate after preplate partition. No doubt further refinements of the identification of molecular markers of early cortical neurons will help to sort out the marginal zone and subplate components of the pioneer cortical axonal projections.

The diversified group of early cortical neurons with their diversified axonal projections that we have considered here has not yet been identified in species other than rodents. However, further study is highly relevant to advancing our understanding of cerebral cortex development. Not only would this support the development of functional murine experimental models, but there is the promise of extending these observations to non-human primates and humans. To emphasize the importance of such a comparative 


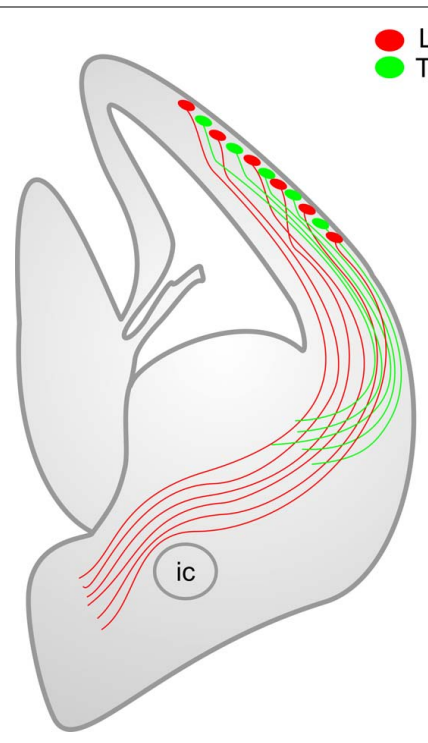

FIGURE 11 | Scheme of the descending corticofugal axonal projections of the two subtypes of non-subplate pioneer neurons at the preplate stage. This scheme highlights the fact that both sets of axons are segregated, although they overlap in a common territory. Note that $\mathrm{L} 1^{+}$axons avoid entering the internal capsule towards the dorsal thalamus. ic, posterior limb of the internal capsule.

approach, it may suffice to consider two examples; namely, the pioneer plate described in humans by Meyer et al. (2000) and the predecessor neurons described in the human preplate by Bystron et al. (2008).

The pioneer plate (Meyer et al., 2000) designates a transient structure in the human preplate formed by $\mathrm{CR}^{+}$pioneer neurons that are split into marginal zone and subplate neuron populations by the arrival of the neurons that form the cortical plate. In our present analysis of the rat cortex, we have seemingly described the same transient arrangement of early-differentiated neurons, which in our case include both $\mathrm{CB}^{+}$and $\mathrm{CR}^{+}$cells, of the preplate and its derivatives. Since the expression of calcium binding proteins may vary widely among species, other markers for human preplate neurons will eventually facilitate comparisons.

It is of historical interest to compare the human pioneer plate model with the preplate partition model first suggested by MarinPadilla (1971), where the primordial plexiform layer or preplate divides into an upper layer that contains Cajal-Retzius cells and a lower layer containing projection neurons. In the model of Meyer et al. (2000), the partition of the preplate occurs by separating early projection neurons of the preplate. From our point of view, the

\section{REFERENCES}

Anderson, S.A., Eisenstat, D.D., Shi,L., and Rubenstein, J. L. (1997). Interneuron migration from basal forebrain to neocortex: dependence on Dlx genes. Science 278, 474-476.

Bulfone, A., Smiga, S. M., Shimamura, K., Peterson, A., Puelles, L., and Rubenstein, J. L. (1995). T-brain-1: a homolog of Brachyury whose expression defines molecularly distinct domains within the cerebral cortex. Neuron 15, 63-78.

Bystron, I., Rakic, P., Molnár, Z., and Blakemore, C. (2006). The first neurons of the human cerebral cortex. Nat. Neurosci. 9, 880-886.

Clascá, F., Angelucci, A., and Sur, M. (1995). Layer-specific programs of development in neocortical projection neurons. Proc. Natl. Acad. Sci. U.S.A. 92, 11145-11149.

difference only reflects the fact that the early neuron populations of the cortical primordium are now known to be more diverse than conceived initially. Our results also show that the rodent preplate contains more diversified populations of neurons than those found by Meyer et al. (2000) in their pioneer plate. A case in point is the TAG- $1^{+}$ neurons that first invade the preplate but, immediately after preplate partition, end up in the upper tier of the cortical plate. Thus, a simple model in which a uniform population of preplate cells divides into marginal zone and subplate neuronal populations is insufficient to account for the rodent data that we have presented here.

The predecessor neurons described in the human preplate by Bystron et al. (2008) have not been described as projection neurons. A comparative context may still be useful to explore to what extent these cells are unique to humans or could have homologues in non-primates. Obviously, further advances on the identification of distinct chemical markers in predecessor cells and in other early cortical neurons will facilitate such comparisons between species.

We have described here a close anatomical relationship of pioneer $\mathrm{L}^{+}$axons with migrating GABA interneurons during their exit from the ganglionic eminences to the pallium, along the intermediate zone of the cortex. Other interneurons migrate in a compartment located more laterally, where they acquire spatial relationships with $\mathrm{L}^{+}$and TAG $-1^{+}$axons. TAG- $1^{+}$axons also accumulate below the subplate, and are accompanied by migrating interneurons in this territory. TAG $-1^{+}$axons in the cortical plate could serve as a hypothetical guide for interneurons from the marginal zone or the subplate to the cortical plate (Denaxa et al., 2001). Our observations strongly suggest that $\mathrm{L}^{+}$and $\mathrm{TAG} 1^{+}$corticofugal axons could be a substrate for migration of interneurons along the cortical intermediate zone (see also, McManus et al., 2004), even though a role for L1 in the migration of cortical interneurons has been excluded in in vitro perturbation experiments (Denaxa et al., 2001). The role of TAG-1 in interneuron migration is controversial (Denaxa et al., 2001, 2005; Morante-Oria et al., 2003; Tanaka et al., 2003), although this molecule is active in the control of tangential migration of other neuron cohorts (Kyriakopoulou et al., 2002; Denaxa et al., 2005). The obvious anatomical relationships of migrating interneurons with the different sets of early corticofugal axons described here suggest, however, that this issue merits further analyses.

\section{ACKNOWLEDGMENTS}

Supported by Government of Spain grants BFU2004-04660, BFU2007-60263 and PFI fellowship BES-2005-10986. Thanks to Belén Andrés for excellent technical work and Martín Cortés for Figures 10 and 11. We thank R. F. Hevner, F. J. Rathjen, T. Seki, K. Takeuchi and the Developmental Studies Hybridoma Bank, University of Iowa for antibodies.

de Carlos, J. A., and O’Leary, D. D. (1992). Growth and targeting of subplate axons and establishment of major cortical pathways. J. Neurosci. 12, 1194-1211.

Denaxa, M., Chan, C. H., Schachner, M., Parnavelas, J. G., and Karagogeos, D. (2001). The adhesion molecule TAG1 mediates the migration of cortical interneurons from the ganglionic eminence along the corticofugal fiber system. Development 128 , 4635-4644.

Denaxa, M., Kyriakopoulou, K., Theodorakis, K., Trichas, G., Vidaki, M., Takeda, Y., Watanabe, K., and Karagogeos, D. (2005). The adhesion molecule TAG-1 is required for proper migration of the superficial migratory stream in the medulla but not of cortical interneurons. Dev. Biol. 288, 87-99. 
Dodd, J., Morton, S. B., Karagogeos, D., Yamamoto, M., and Jessell, T. M. (1988). Spatial regulation of axonal glycoprotein expression on subsets of embryonic spinal neurons. Neuron 1 , 105-116.

Fukuda, T., Kawano, H., Ohyama, K., Li, H. P., Takeda, Y., Oohira, A., and Kawamura, K. (1997). Immunohistochemical localization of neurocan and $\mathrm{L} 1$ in the formation of thalamocortical pathway of developing rats. J. Comp. Neurol. 382, 141-152.

García-Moreno, F., López-Mascaraque, L., and de Carlos, J. A. (2007). Origins and migratory routes of murine CajalRetzius cells. J. Comp. Neurol. 500, 419-432.

Gong, S., Zheng, C., Doughty, M. L., Losos, K., Didkovsky, N., Schambra, U. B., Nowak, N. J., Joyner, A., Leblanc, G., Hatten, M. E., and Heintz, N. (2003). A gene expression atlas of the central nervous system based on bacterial artificial chromosomes. Nature 425, 917-925.

Hevner, R. F., Neogi, T., Englund, C., Daza, R. A., and Fink, A. (2003). CajalRetzius cells in the mouse: transcription factors, neurotransmitters, and birthdays suggest a pallial origin. Dev. Brain Res. 141, 39-53.

Hevner, R. F., Shi, L., Justice, N., Hsueh, Y., Sheng, M., Smiga, S., Bulfone, A., Goffinet, A. M., Campagnoni, A. T., and Rubenstein J. L. (2001). Tbrl regulates differentiation of the preplate and layer 6. Neuron 29, 353-366.

Hevner, R. F., and Zecevic, N. (2006). Pioneer neurons and interneurons in the developing subplate: molecular markers, cell birthdays, and neurotransmitters. In Development and Plasticity in Sensory Thalamus and Cortex, R.S. Erzurumlu,W.Guido and Z. Molnár, eds (New York, Springer), pp. 1-17.

Hoerder-Suabedissen,A., Wang, W.Z., Lee, S., Davies, K. E., Goffinet, A. M., Rakić, S., Parnavelas, J., Reim, K., Nicolić, M., Paulsen, O., and Molnár, Z. (2009). Novel markers reveal subpopulations of subplate neurons in the murine cerebral cortex. Cereb. Cortex 19, 1738-1750.
Jacobs, E. C., Campagnoni, C., Kampf, K., Reyes, S. D., Kalra, V., Handley, V., Xie, Y. Y., Hong-Hu, Y., Spreur, V., Fisher, R. S., and Campagnoni, A. T. (2007). Visualization of corticofugal projections during early cortical development in a tau-GFP-transgenic mouse. Eur. J. Neurosci. 25, 17-30.

Kyriakopoulou, K., de Diego, I., Wassef, M., and Karagogeos, D. (2002). A combination of chain and neurophilic migration involving the adhesion molecule TAG- 1 in the caudal medulla. Development 129, 287-296.

Liu, F.-C., and Graybiel, A. M. (1992). Transient calbindin-D28K-positive system in the telencephalon: ganglionic eminence, developing striatum and cerebral cortex. J. Neurosci. 12, 647-690.

López-Bendito, G., Shigemoto, R., Fairén, A., and Luján, R. (2002a). Differential distribution of group I metabotropic glutamate receptors during rat cortical development. Cereb. Cortex 12, 625-638.

López-Bendito, G., Shigemoto, R., Kulik, A., Paulsen, O., Fairén, A., and Luján, R. (2002b). Expression and distribution of metabotropic GABA receptor subtypes $\mathrm{GABA}_{\mathrm{B}} \mathrm{R} 1$ and $\mathrm{GABA}_{\mathrm{B}} \mathrm{R} 2$ during rat neocortical development. Eur. J. Neurosci. 15, 1766-1778.

Marin-Padilla, M. (1971). Early prenatal ontogenesis of the cerebral cortex (neocortex) of the cat (Felis domestica). A Golgi study. I. The primordial neocortical organization. Z. Anat. Entwicklungsgesch. 134, 117-145.

McConnell, S. K., Ghosh, A., and Shatz C. J. (1989). Subplate neurons pioneer the first axon pathway from the cerebral cortex. Science 245, 978-982.

McManus, M. F., Nasrallah, I. M., Gopal, P. P., Baek, W.S., and Golden, J. A. (2004). Axon mediated interneuron migration. J. Neuropathol. Exp. Neurol. 63, 932-941.

Meyer G., Goffinet A. M., and Fairén A. (1999). What is a Cajal-Retzius cell? A reassessment of a classical cell type based on recent observations in the developing neocortex. Cereb. Cortex 9, 765-775.

Meyer, G., Schaaps, J. P., Moreau, L., and Goffinet, A. M. (2000). Embryonic and early fetal development of the human neocortex. J. Neurosci. 20, 1858-1868.

Meyer, G., Soria, J. M., Martínez-Galán, J. R., Martín-Clemente, B., and Fairén,A. (1998). Different origins and developmental histories of transient neurons in the marginal zone of the fetal and neonatal rat cortex. J. Comp. Neurol. 397, 493-518.

Molnár, Z., Adams, R., and Blakemore, C. (1998). Mechanisms underlying the early establishment of thalamocortical connections in the rat. J. Neurosci. 18 , 5723-5745.

Molnár, Z., and Cordery, P. (1999). Connections between cells of the internal capsule, thalamus, and cerebral cortex in embryonic rat. J. Comp. Neurol. 413, 1-25.

Morante-Oria, J., Carleton, A., Ortino, B., Kremer, E. J., Fairén, A., and Lledo, P. M. (2003). Subpallial origin of a population of projecting pioneer neurons during corticogenesis. Proc. Natl. Acad. Sci. U.S.A. 100, 12468-12473.

Osheroff, H., and Hatten, M. E. (2009). Gene expression profiling of preplate neurons destined for the subplate: genes involved in transcription, axon extension, neurotransmitter regulation, steroid hormone signaling, and neuronal survival. Cereb. Cortex 19(Suppl. 1), i126-i134.

Puelles, L., Kuwana, E., Puelles, E. Bulfone, A., Shimamura, K., Keleher, J., Smiga, S., and Rubenstein, J. L. (2000). Pallial and subpallial derivatives in the embryonic chick and mouse telencephalon, traced by the expression of the genes Dlx-2, Emx-1, Nkx-2.1, Pax-6, and Tbr-1. J. Comp. Neurol. 424, 409-438.

Soria, J. M., and Fairén, A. (2000). Cellular mosaics in the rat marginal zone define an early neocortical territorialization. Cereb. Cortex. 10, 400-412.

Soria, J. M., Martínez-Galán, J. R., Luján, R., Valdeolmillos, M., and Fairén, A. (1999). Functional NMDA and $\mathrm{GABA}_{\mathrm{A}}$ receptors in pioneer neurons of the cortical marginal zone. Eur. J. Neurosci. 11, 3351-3354.

Tamamaki, N., Yanagawa, Y., Tomioka, R., Miyazaki., J, Obata, K., and Kaneko,
T. (2003). Green fluorescent protein expression and colocalization with calretinin, parvalbumin, and somatostatin in the GAD67-GFP knock-in mouse. J. Comp. Neurol. 467, 60-79.

Tanaka, D., Nakaya, Y., Yanagawa, Y., Obata, K., and Murakami, F. (2003). Multimodal tangential migration of neocortical GABAergic neurons independent of GPI-anchored proteins. Development 130, 5803-5813.

Weisenhorn,D.M.,Prieto, E.W., and Celio, M.R.(1994). Localization of calretinin in cells of layer I (Cajal-Retzius cells) of the developing cortex of the rat. Dev. Brain Res. 82, 293-297.

Wolfer, D. P., Henehan-Beatty,A., Stoeckli, E. T., Sonderegger, P., and Lipp H. P. (1994). Distribution of TAG-1/axonin1 in fibre tracts and migratory streams of the developing mouse nervous system. J. Comp. Neurol. 345, 1-32.

Yamazaki, H., Sekiguchi, M., Takamatsu, M., Tanabe, Y., and Nakanishi, S. (2004). Distinct ontogenic and regional expressions of newly identified Cajal-Retzius cellspecific genes during neocorticogenesis. Proc. Natl. Acad. Sci. U.S.A. 101, 14509-14514.

Conflict of Interest Statement: The authors declare that the research was conducted in the absence of any commercial or financial relationships that could be construed as a potential conflict of interest.

Received: 06 August 2009; paper pending published: 29 August 2009; accepted: 04 November 2009; published online: 17 November 2009.

Citation: Espinosa A, Gil-Sanz C, Yanagawa $Y$ and Fairén A (2009) Two separate subtypes of early non-subplate projection neurons in the developing cerebral cortex of rodents. Front. Neuroanat. 3:27. doi: 10.3389/neuro.05.027.2009

Copyright (c) 2009 Espinosa, Gil-Sanz, Yanagawa and Fairén. This is an openaccess article subject to an exclusive license agreement between the authors and the Frontiers Research Foundation, which permits unrestricted use, distribution, and reproduction in any medium, provided the original authors and source are credited. 